\title{
Minireview
}

\section{The new molecular biology of granulosa cell tumors of the ovary}

\author{
Nicolas Kalfa*†, Reiner A Veitia $\$$, Bérénice A Benayoun $¥ \S$, Brigitte Boizet-Bonhoureף \\ and Charles Sultan $*$
}

\begin{abstract}
Addresses: *Service d'Hormonologie, Hôpital Lapeyronie, CHU Montpellier et UM1, Montpellier, France. †Service de Chirurgie Pédiatrique, Hôpital Lapeyronie, CHU Montpellier, Montpellier, France. 林stitut Jacques Monod, CNRS-UMR 7592, Bâtiment Buffon, 15 Rue Hélène Brion, 75013 Paris, France. §Université Paris Diderot, Paris 7, 75013 Paris, France. TInstitut de Génétique Humaine, CNRS UPR1142, Montpellier, France. $¥$ Unité d’Endocrinologie-Gynécologie Pédiatriques, CHU Montpellier et UM1, Montpellier, France
\end{abstract}

Correspondence: Charles Sultan. Email: c-sultan@chu-montpellier.fr

\begin{abstract}
Granulosa cell tumors (GCTs) of the ovary belong to the group of ovarian sex-cord stromal tumors and represent 5 to $10 \%$ of ovarian malignancies. GCTs exhibit several morphological, biochemical and hormonal features of normal proliferating preovulatory granulosa cells, such as estrogen biosynthesis. Prognostic factors of this condition are lacking, and alternative treatment options to preserve future fertility are needed. Several groups have shown that two genetic factors implicated in GCTs are of particular interest. The gsp oncogene is a constitutive activating mutation of the Gsa subunit and is correlated with the prognosis of the tumor. FOXL2 is a transcription factor gene involved in ovarian development and function, whose expression is reduced and which is mutated in the majority of GCTs. FOXL2 appears to play a major role in cell cycle regulation. These recent findings open new pathophysiological insights into GCT development as well as revisitation of granulosa cell and ovarian function.
\end{abstract}

\section{Natural history of granulosa cell tumors of the ovary}

Granulosa cell tumors (GCTs) of the ovary are relatively uncommon neoplasms, representing approximately 5 to $10 \%$ of all ovarian malignancies [1,2]; the others are germ cell tumors (teratomas and yolk sac tumors, 60 to $70 \%$ ) and epithelial adenomas (10 to 20\%) [3]. GCTs of the ovary belong to the group of ovarian sex-cord stromal tumors. Other tumors in this class are thecoma-fibromas, Sertoli cell tumors, sex cord tumors with annular tubules, and gynandroblastomas. The majority of patients with GCTs are adults, but $5 \%$ are pre- or peri-pubertal [4]. Consequently, two histological types of GCTs can be distinguished on a histopathological basis: juvenile and adult. GCTs exhibit several morphological, biochemical and hormonal features of normal proliferating pre-ovulatory granulosa cells, including both estrogen and inhibin biosynthesis [5]. This tumoral hyperestrogenism induces precocious puberty in children (premature breast development, vaginal bleeding) and advanced growth and bone maturation. The prognosis of juvenile GCTs is excellent overall: tumor recurrence and metastasis are rare and usually occur early [6]. On the other hand, adult GCTs are low-grade indolent malignant neoplasms that display a significant propensity for recurrence and metastasis, and they may cause menorrhagia or intermenstrual bleeding. The cornerstone of treatment remains surgery. The disease in young patients is often confined to one ovary and thus, in order to preserve fertility, a unilateral salpingo-oophorectomy is preferable. In the case of postmenopausal women, a total abdominal hysterectomy and bilateral salpingo-oophorectomy should be performed [7].

\section{Challenges in GCT management}

Nevertheless, management of patients with ovarian GCTs needs to be improved. First, the recurrent or metastatic tumor may manifest many years after removal of the primary neoplasm, with intervals of 10 or even 20 years being not uncommon, especially in the adult disease $[8,9]$. Clinical follow-up of these patients is thus critical, but prognostic factors are lacking and assessment of the recurrence risk remains imprecise. For instance, in International Federation of Obstetricians and Gynecologists (FIGO) stage I disease (that is, intra-ovarian tumor with no extension, the most frequent stage at diagnosis according to FIGO), no association between outcome and the clinical signs or tumor histology (mitotic, nuclear atypia, ploidy, Ki67 expression) has been undisputedly demonstrated $[10,11]$. Furthermore, in more advanced disease, aggressive debulking surgery and postoperative chemotherapy may be required [8]. Alternative treatment options and the use of molecular markers are thus necessary, especially for young women whose fertility should be preserved.

\section{FOXL2 and GCTs of the ovary}

FOXL2 is a recent candidate gene in the pathophysiology of GCTs and could prove useful to evaluate their prognosis.

FIGO, International Federation of Obstetricians and Gynaecologists; FOXL2, forkhead transcription factor FOXL2; FSH, follicle-stimulating hormone; GCT, granulosa cell tumor; PKA, cAMP-dependent protein kinase; RFLP, restriction fragment length polymorphism; WT1, Wilms' tumor suppressor gene. 
Indeed, FOXL2 is a winged helix/forkhead transcription factor gene involved in ovarian development and function $[12,13]$. FOXL2 ovarian expression in mammals starts before the morphological differentiation of the gonad is recognizable, and persists until adulthood, mainly in granulosa cells $[14,15]$. FOXL2 is thought to be a key factor in the early development and maintenance of the vertebrate ovary $[12,15]$. Its expression in granulosa cells is suppressed, or at least lowered, in the majority of juvenile GCTs, particularly in those with the most aggressive pattern of progression [16]. Similar expression studies have yet to be performed in adult GCTs.

Interestingly, Shah et al. [17] recently studied four adult GCTs using whole-transcriptome paired-end RNA sequencing. After removing the previously described germline genetic variants and non-specific mutations present in non-GCTs, the authors identified the somatic missense point mutation c. $402 \mathrm{C} \rightarrow \mathrm{G}$ (p. $\mathrm{C} 134 \mathrm{~W})$ in all four specimens. Subsequently, they used direct sequencing, restriction fragment length polymorphism analyses (RFLPs), and a real-time PCR-based allelic discrimination assay to genotype FOXL2 in a large collection of tumors. The p. C134W mutation was found in $97 \%$ of 89 additional adult GCTs studied, and was detected in only one case out of eight juvenile GCTs. The mutation was also found in $21 \%$ of thecomas, that is, 3 out of 14, in the study of Shah et al. Further studies are needed to determine the link between this mutation and GCTs, and whether this mutation alone is sufficient to induce tumor progression.

\section{Other genetic factors implicated in ovarian GCTs}

Genetic defects in other signaling pathways have been investigated in GCTs. Although Peutz-Jeghers syndrome is associated with an increased risk for GCTs, neither allele loss at the disease locus (19p13.3) nor mutations in the $L K B 1$ gene are associated with sporadic GCTs $[18,19]$. Similarly, despite the association of epithelial ovarian cancer with the familial breast cancer genes $B R C A 1$ and $B R C A 2$, sporadic mutations have not been reported for GCTs.

Other interesting candidate pathways are those involving the mitogen-activated protein kinases [20] and growth factors, because they are known to induce increased oncogene functioning or a loss-of-anti-oncogene function in several solid tumors. However, King et al. [21] failed to identify any prognostic value for the oncogenes $c$-myc, p21-ras, c-erb B2, and p53 in a group of 40 GCTs. Similarly, the Wilms' tumor suppressor gene (WT1) and TP53 genes, which play a role in follicular development, have been tested [22]. WT1 is expressed in GCT, but neither mutations nor loss of heterozygosity have been identified [23]. TP53 mutations are frequent in numerous cancers, especially in epithelial tumors of the ovary, but there is neither hyperexpression [24] nor mutation [25] of this gene in GCT.
The role of the follicle-stimulating hormone (FSH) signaling pathway is also strongly suspected in GCTs for two reasons: firstly, normal granulosa cells are under the control of FSH and, secondly, the gene expression profile of GCTs is consistent with a constitutive activation of FSH signaling [26]. However, there is no evidence of activating mutations in the gene encoding the FSH receptor [27-29]. FSH signaling involves the coupling of heterotrimeric G proteins to activate intracellular second messenger systems, mainly the cAMP-dependent protein kinase (PKA).

Conflicting data have been reported regarding the presence of a constitutive activating mutation of the Gsa subunit in GCTs, the so-called $g s p$ oncogene. It has rarely been described in adult GCTs [30,31], but our group has identified it frequently in the juvenile type, where mutations in hot spot position 201 (p.R201C or p.R201H) were found in $30 \%$ of patients [32]. The precise role of this mutation in the transformation of ovarian cells into malignant cells remains unclear, but it has been demonstrated in other tissues that the rate of cell proliferation and invasiveness can be influenced by the constitutive activation of Gas [33]. The oncological stages are indeed significantly different according to the $g s p$ oncogene status. Patients with a hyperactivated Gsa exhibit significantly more advanced tumors, and almost $80 \%$ of $g s p$ positive patients present with an extra-ovarian extension (stage Ic) or have a recurrence [32].

\section{Potential diagnostic and therapeutic applications}

The clinical applications of these findings may be promising in the near future, for several reasons. Firstly, identification of a recurrent mutation in FOXL2 may be used as another diagnostic tool for adult GCTs, in addition to the classical pathological and immunohistochemical features. It may be particularly useful to explore granulosa tumor participation in heterogeneous ovarian non-germinal tumors with components of different origins. Also, the low frequency of the FOXL2 mutation in juvenile GCTs compared with adult cases, as reported by Shah and collaborators [17], supports the distinction made between the juvenile type and the adult type based on clinical presentation, pathological features and natural progression [1]. Clearly, differentiating the two types of tumor is clinically relevant, since relapses of adult GCTs are more frequent and may occur later than juvenile GCTs. The mutational or expressional status of FOXL2 could thus be of importance in adapting the length of postoperative follow-up. Another genetic abnormality that could be critical in the follow-up of these patients is the $g s p$ oncogene status, especially for juvenile GCTs. A constitutively activated Gsa is indeed involved in the natural history of the tumor and is a prognostic factor of its extension. Finally, the finding of both extinction [16] and mutation [17] of FOXL2 in GCTs highlights the role of this 
gene in the regulation of cell proliferation. These findings increase the body of evidence implicating the FOX family genes, whether as oncogenes or anti-oncogenes, in malignant processes such as rhabdomyosarcomas [34], secondary acute myeloblastic leukemia [35], and laryngeal, lung, breast [36-38] and pancreatic cancers [39]. FOXL2 may act as a transcriptional regulator and a coordinator of SMAD3 downstream targets $[40,41]$ that, with SMAD2 and the TGF- $\beta$ superfamily ligands, regulate granulosa cell proliferation [42]. These recently identified steps could be the targets of the next generation of therapies.

\section{Competing interests}

The authors declare that they have no competing interests.

\section{Acknowledgements}

We would like to acknowledge $\mathrm{Dr}$ and $\mathrm{Pr} F$ Paris, Unité d'endocrinologie pédiatrique, Hôpital Aranud-de-Villeneuve, CHU Montpellier, France; $\mathrm{P}$ Philibert and A Ecochard, Service d'Hormonologie, Hôpital Lapeyronie, CHU Montpellier, France; C Patte, Département d'Oncologie, Institut Gustave Roussy, Villejuif, France; E Thibaud, Service d'Endocrinologie Pédiatrique, Hôpital Necker, Paris, France; C Pienkowski, Service d'Endocrinologie Pédiatrique, Hôpital des Enfants, CHU Toulouse, France; M Fellous, Génétique Humaine, Inserm 709, Université Paris 7, Hôpital Cochin, Paris, France; and F Jaubert, Service d'anatompathologie, Hôpital Necker, Paris, France, for their contribution in this work. This work was supported by a national grant from the Association de Recherche contre le Cancer (ARC: JR/MLD/MDV-P05/5).

\section{References}

1. Schumer ST, Cannistra SA: Granulosa cell tumor of the ovary. J Clin Oncol 2003, 21:1180-1189.

2. Colombo N, Parma G, Zanagnolo V, Insinga A: Management of ovarian stromal cell tumors. J Clin Oncol 2007, 25:29442951.

3. Merras-Salmio L, Vettenranta K, Mottonen M, Heikinheimo M: Ovarian granulosa cell tumors in childhood. Pediatr Hematol Oncol 2002, 19:145-156.

4. Young RH, Dickersin GR, Scully RE: Juvenile granulosa cell tumor of the ovary. A clinicopathological analysis of $\mathbf{1 2 5}$ cases. Am J Surg Pathol 1984, 8:575-596.

5. Fuller PJ, Chu S, Fikret S, Burger HG: Molecular pathogenesis of granulosa cell tumours. Mol Cell Endocrinol 2002, 191:89-96.

6. Kalfa N, Patte C, Orbach D, Lecointre C, Pienkowski C, Philippe F, Thibault E, Plantaz D, Brauner R, Rubie H, Guedj AM, Ecochard A, Paris F, Jeandel C, Baldet P, Sultan C: A nationwide study of granulosa cell tumors in pre- and postpubertal girls: missed diagnosis of endocrine manifestations worsens prognosis. J Pediatr Endocrinol Metab 2005, 18:25-31.

7. Evans AT, 3rd, Gaffey TA, Malkasian GD, Jr., Annegers JF: Clinicopathologic review of 118 granulosa and 82 theca cell tumors. Obstet Gynecol 1980, 55:231-238.

8. Pectasides D, Papaxoinis G, Fountzilas G, Aravantinos G, Pectasides E, Mouratidou D, Economopoulos T, Andreadis C: Adult granulosa cell tumors of the ovary: a clinicopathological study of 34 patients by the Hellenic Cooperative Oncology Group (HeCOG). Anticancer Res 2008, 28(2B): 1421-1427.

9. Hasiakos D, Papakonstantinou K, Karvouni E, Fotiou S: Recurrence of granulosa cell tumor 25 years after initial diagnosis. Report of a case and review of the literature. Eur J Gynaecol Oncol 2008, 29:86-88.

10. Leuverink EM, Brennan BA, Crook ML, Doherty DA, Hammond IG, Ruba S, Stewart CJ: Prognostic value of mitotic counts and Ki-67 immunoreactivity in adult-type granulosa cell tumour of the ovary. J Clin Pathol 2008, 61:914-919.

11. Kalfa N, Sultan C: Juvenile ovarian granulosa cell tumor: a benign or malignant condition? Gynecol Endoc 2009, 25: 299.

12. Schmidt D, Ovitt CE, Anlag K, Fehsenfeld S, Gredsted L, Treier $\mathrm{AC}$, Treier M: The murine winged-helix transcription factor Foxl2 is required for granulosa cell differentiation and ovary maintenance. Development 2004, 131:933-942.

13. Uda M, Ottolenghi C, Crisponi L, Garcia JE, Deiana M, Kimber W, Forabosco A, Cao A, Schlessinger D, Pilia G: Foxl2 disruption causes mouse ovarian failure by pervasive blockage of follicle development. Hum Mol Genet 2004, 13:1171-1181.

14. Cocquet J, Pailhoux E, Jaubert F, Servel N, Xia X, Pannetier M, De Baere E, Messiaen L, Cotinot C, Fellous M, Veitia RA: Evolution and expression of FOXL2. J Med Genet 2002, 39: 916-921.

15. Cocquet J, De Baere E, Gareil M, Pannetier M, Xia X, Fellous $M$, Veitia RA: Structure, evolution and expression of the FOXL2 transcription unit. Cytogenet Genome Res 2003, 101: 206-211.

16. Kalfa N, Philibert $P$, Patte $C$, Ecochard A, Duvillard $P$, Baldet $P$, Jaubert F, Fellous M, Sultan C: Extinction of FOXL2 expression in aggressive ovarian granulosa cell tumors in children. Fertil Steril 2007, 87:896-901.

17. Shah SP, Köbel M, Senz J, Morin RD, Clarke BA, Wiegand KC, Leung G, Zayed A, Mehl E, Kalloger SE, Sun M, Giuliany R, Yorida E, Jones S, Varhol R, Swenerton KD, Miller D, Clement PB, Crane C, Madore J, Provencher D, Leung P, DeFazio A, Khattra J, Turashvili G, Zhao Y, Zeng T, Glover JN, Vanderhyden B, Zhao C, et al.: Mutation of FOXL2 in granulosa-cell tumors of the ovary. N Engl J Med 2009, 360:27192729.

18. Wang ZJ, Churchman M, Campbell IG, Xu WH, Yan ZY, McCluggage WG, Foulkes WD, Tomlinson IP: Allele loss and mutation screen at the Peutz-Jeghers (LKB1) locus (19p13.3) in sporadic ovarian tumours. Br J Cancer 1999, 80:70-72.

19. Kato N, Romero M, Catasus L, Prat J: The STK11/LKB1 Peutz-Jegher gene is not involved in the pathogenesis of sporadic sex cord-stromal tumors, although loss of heterozygosity at $19 \mathrm{p} 13.3$ indicates other gene alteration in these tumors. Hum Pathol 2004, 35:1101-1104.

20. Kim K, Lindstrom MJ, Gould MN: Regions of H- and K-ras that provide organ specificity/potency in mammary cancer induction. Cancer Res 2002, 62:1241-1245.

21. King LA, Okagaki T, Gallup DG, Twiggs LB, Messing MJ, Carson LF: Mitotic count, nuclear atypia, and immunohistochemical determination of Ki-67, c-myc, p21-ras, c-erbB2, and p53 expression in granulosa cell tumors of the ovary: mitotic count and $\mathrm{Ki}-67$ are indicators of poor prognosis. Gynecol Oncol 1996, 61:227-232.

22. Makrigiannakis A, Amin K, Coukos G, Tilly JL, Coutifaris C: Regulated expression and potential roles of p53 and Wilms' tumor suppressor gene (WT1) during follicular development in the human ovary. $J$ Clin Endocrinol Metab 2000, 85:449-459.

23. Coppes MJ, Ye Y, Rackley R, Zhao XL, Liefers GJ, Casey G, Williams BR: Analysis of WT1 in granulosa cell and other sex cord-stromal tumors. Cancer Res 1993, 53:2712-2714.

24. Liu FS, Ho ES, Lai CR, Chen JT, Shih RT, Yang CH, Tsao CM: Overexpression of p53 is not a feature of ovarian granulosa cell tumors. Gynecol Oncol 1996, 61:50-53.

25. Kappes S, Milde-Langosch K, Kressin P, Passlack B, Dockhorn-Dworniczak B, Rohlke P, Loning T: p53 mutations in ovarian tumors, detected by temperature-gradient gel electrophoresis, direct sequencing and immunohistochemistry. Int J Cancer 1995, 64:52-59.

26. Chu S, Rushdi S, Zumpe ET, Mamers P, Healy DL, Jobling T, Burger HG, Fuller PJ: FSH-regulated gene expression profiles in ovarian tumours and normal ovaries. Mol Hum Reprod 2002, 8:426-433. 
27. Fuller PJ, Verity K, Shen Y, Mamers P, Jobling T, Burger HG: No evidence of a role for mutations or polymorphisms of the follicle-stimulating hormone receptor in ovarian granulosa cell tumors. J Clin Endocrinol Metab 1998, 83:274-279.

28. Kotlar T, Young RH, Albanese C, Crowley WF Jr, Scully RE, Jameson JL: Absence of mutations in the FSH receptor in ovarian granulosa cell tumors. J Clin Endocrinol Metab 1998, 83:3001.

29. Bas F, Pescovitz $\mathrm{OH}$, Steinmetz R: No activating mutations of FSH receptor in four children with ovarian juvenile granulosa cell tumors and the association of these tumors with central precocious puberty. J Pediatr Adolesc Gynecol 2009, 22:173-179.

30. Fragoso $M C$, Latronico $A C$, Carvalho FM, Zerbini MC, Marcondes JA, Araujo LM, Lando VS, Frazzatto ET, Mendonca BB, Villares SM: Activating mutation of the stimulatory $\mathbf{G}$ protein (gsp) as a putative cause of ovarian and testicular human stromal Leydig cell tumors. J Clin Endocrinol Metab 1998, 83:2074-2078.

31. Ligtenberg $M J$, Siers $M$, Themmen AP, Hanselaar TG, Willemsen W, Brunner HG: Analysis of mutations in genes of the follicle-stimulating hormone receptor signaling pathway in ovarian granulosa cell tumors. $J$ Clin Endocrinol Metab 1999, 84:2233-2234.

32. Kalfa N, Ecochard A, Patte C, Duvillard P, Audran F, Pienkowski C, Thibaud E, Brauner R, Lecointre C, Plantaz D, Guedj AM, Paris F, Baldet P, Lumbroso S, Sultan C: Activating mutations of the stimulatory $\mathrm{g}$ protein in juvenile ovarian granulosa cell tumors: a new prognostic factor? J Clin Endocrinol Metab 2006, 91:1842-1847.

33. Chien J, Wong E, Nikes E, Noble MJ, Pantazis CG, Shah GV: Constitutive activation of stimulatory guanine nucleotide binding protein (G(S)alphaQL)-mediated signaling increases invasiveness and tumorigenicity of $\mathrm{PC}-3 \mathrm{M}$ prostate cancer cells. Oncogene 1999, 18:3376-3382.

34. Barr FG: Gene fusions involving PAX and FOX family members in alveolar rhabdomyosarcoma. Oncogene 2001, 20:5736-5746.

35. Hillion J, Le Coniat $\mathrm{M}$, Jonveaux $\mathrm{P}$, Berger $\mathrm{R}$, Bernard OA: AF6q21, a novel partner of the MLL gene in $t(6 ; 11)$ (q21;q23), defines a forkhead transcriptional factor subfamily. Blood 1997, 90:3714-3719.
36. Mani H, Shilo K, Galvin JR, Stocker JT, Franks TJ: Spectrum of precursor and invasive neoplastic lesions in type 1 congenital pulmonary airway malformation: case report and review of the literature. Histopathology 2007, 51:561-565.

37. Mani N, Lowe D, Pope L, El-Daly H, Pfleiderer A: An unusual case of laryngeal spindle cell carcinoma metastasising to the orbit and heart. J Laryngol Otol 2007, 121:e19.

38. Mani SA, Yang J, Brooks M, Schwaninger G, Zhou A, Miura N, Kutok JL, Hartwell K, Richardson AL, Weinberg RA: Mesenchyme Forkhead 1 (FOXC2) plays a key role in metastasis and is associated with aggressive basal-like breast cancers. Proc Natl Acad Sci USA 2007, 104:1006910074

39. Nakamura T, Furukawa $Y$, Nakagawa H, Tsunoda T, Ohigashi $\mathrm{H}$, Murata K, Ishikawa O, Ohgaki K, Kashimura N, Miyamoto $M$, Hirano S, Kondo S, Katoh $H$, Nakamura $Y$, Katagiri T: Genome-wide cDNA microarray analysis of gene expression profiles in pancreatic cancers using populations of tumor cells and normal ductal epithelial cells selected for purity by laser microdissection. Oncogene 2004, 23:23852400.

40. Blount AL, Schmidt $K$, Justice NJ, Vale WW, Fischer WH, Bilezikjian LM: FoxL2 and Smad3 coordinately regulate follistatin gene transcription. J Biol Chem 2009, 284:76317645.

41. Ellsworth BS, Burns AT, Escudero KW, Duval DL, Nelson SE Clay CM: The gonadotropin releasing hormone (GnRH) receptor activating sequence (GRAS) is a composite regulatory element that interacts with multiple classes of transcription factors including Smads, AP-1 and a forkhead DNA binding protein. Mol Cell Endocrinol 2003, 206:93-111.

42. Dragovic RA, Ritter LJ, Schulz SJ, Amato F, Thompson JG, Armstrong DT, Gilchrist RB: Oocyte-secreted factor activation of SMAD $2 / 3$ signaling enables initiation of mouse cumulus cell expansion. Biol Reprod 2007, 76:848-857.

Published: 25 August 2009

doi:10.1186/gm81

(c) 2009 BioMed Central Ltd 